\title{
Genetic Variability Analysis in Greater Yam (Dioscorea alata L.) in Southern Rajasthan Conditions
}

\author{
Vandna $^{1 *}$, K. D. Ameta ${ }^{1}$, R. A. Kaushik ${ }^{1}$ and M. K. Meena ${ }^{2}$ \\ ${ }^{1}$ Department of Horticulture, Rajasthan College of Agriculture, Maharana Pratap University \\ of Agriculture \& Technology, Udaipur (Rajasthan)-313001, India \\ ${ }^{2}$ Rajasthan Agricultural Research Institute Durgapura, Jaipur (Rajasthan) \\ *Corresponding author
}

\begin{abstract}
A B S T R A C T
\section{Keywords}

Genetic variability, Dioscoreaalata, heritability, Germplasm, GCV, PCV, Genetic advance etc

Article Info

Accepted:

28 July 2020

Available Online:

10 August 2020

An experiment was carried out on study of genetic variability in 30 genotypes of greater yam at Department of Horticulture, Rajasthan College of Agriculture, Maharana Pratap University of Agriculture and Technology, Udaipur during kharif season 2018-19. Observations were recorded on 22 growth and quality characters viz., days to emergence, first leaf emergence, number of leaves (30 DAE), number of sprouts per seedtuber, vine length at $45 \mathrm{DAE}$, internode length, vine length at harvest, leaf width, petiole length, tuber length, diameter of tuber, number of tuber per vine, weight of tuber, stem girth, tuber yield per vine, starch, ascorbic acid, moisture, TSS, total sugar, total Phenol, dry matter. The analysis of variance indicated that the mean sum of square due to genotypes were highly significant for all the characters suggesting the presence of good amount of variability in material studied. The estimates of GCV and PCV, heritability, genetic advance \& genetic gain were higher for evaluated traits.
\end{abstract}

\section{Introduction}

Dioscorea alata L. (greater yam or ratalu or ubibadak or winged yam) is a monocotyledonous tuber crop of the Dioscoreaceae family and is reported to be an old crop species native to South-East Asia. Greater yam is a dioecious species with a ploidy level ranging from $2 n=2 x=40$ to $2 n$ $=4 \mathrm{x}=80$. The tubers are mainly consumed as a vegetable. The peeled tubers are usually boiled, roasted or cut into pieces that are fried in oil. They are also useful for processed products including fries, chips, instant flakes and flour. It has been used as a moderate laxative and vermifuge, for fever, gonorrhoea, leprosy, tumors and inflamed haemorrhoids. Yam is rich source of three minerals namely calcium, phosphorus and iron. The vitamin contents of yam tubers include carotene (provitamin A), thiamine, riboflavin, niacin and ascorbic acid. It is valued for the starch that can be processed from it. The success of the breeding programme is largely determined by the genetic diversity as well as by key parameters related to adaptation and productivity. Therefore, these activities need information about estimation of genotypic and 
phenotypic variance, heritability value, and genetic advance on the character to be repaired, as well as the important characters. Hence, the present investigation was carried out to elicit information on the nature and magnitude of variability existing in the genotypes collected from different placesso that different germplasm can be evaluated to develop new improved cultivars for the farmers.

\section{Materials and Methods}

The experimental material comprising 30 genotypes of greater yam were collected from different places and the quality parameters were studied at the Hi-Tech unit, Department of Horticulture, Rajasthan College of Agriculture, Maharana Pratap University of Agriculture and Technology, Udaipur during kharif(June 2018 to February 2019).The observations were recorded on different growth and quality characters viz., days to emergence, first leaf emergence, number of leaves (30 DAE), number of sprouts per seedtuber, vinelength at $45 \mathrm{DAE}$, internode length, vine length at harvest, leaf width, petiole length, tuber length, diameter of tuber, number of tuber per vine, weight of tuber, stem girth, tuber yield per vine, starch, ascorbic acid, moisture, TSS, total sugar, total Phenol, dry matter. Five randomly selected plants for each genotype were considered for observations of different characters.

The data were statistically analyzed to calculate various genetic parameters viz., genotypic and phenotypic coefficients of variation (GCV and PCV), heritability in broad sense and expected genetic advance. Variability that existed in the population for various characters was estimated by the method suggested by Burton (1952). Heritability in broad sense was estimated by the formula given by Burton and De vane (1953) and Hanson et al., (1956).The genetic advance of the genotypes at 5\% selection pressure was calculated using the formula suggested by Johnson et al., (1955).

\section{Results and Discussion}

\section{Analysis of variance}

The analysis of variance for characters under study is presented in Table 1. Analysis of variance indicated that mean squares due to genotypes were highly significant for all characters. Significant mean revealed existence of considerable variability in material studied for improvement of various traits.

\section{Variability parameters}

Genotypic and phenotypic coefficient of variation (GCV \& PCV) for different characters are presented in Table 2. High magnitude of genotypic as well as phenotypic coefficient of variation were recorded for traits viz., number of tuber per vine $(23.30 \%$ and $25.15 \%$ ), weight of tuber $(37.57 \%$ and $38.17 \%)$ tuber yield per vine $(28.59 \%$ and $29.40 \%)$, ascorbic acid (20.17\% and 20.61 $\%)$ and total sugar (20.24\% and $20.28 \%$ ).

The phenotypic coefficient of variation ranged from $1.29 \%$ in total phenol to 38.83 $\%$ in case of weight of tuber. The PCV estimates in all the characters showed that the variability was low $(<10 \%)$ in case of starch content, moisture, total phenol; moderate (10$20 \%$ ) for first leaf emergence, number of leaves, number of sprouts per seed tuber, vine length (45 DAE), internodal length, vine length at harvest, leaf width, petiole length, tuber length, diameter of tuber, stem girth, TSS, dry matter and high $(>20 \%)$ for days to emergence, number of tuber per vine, weight of tuber, tuber yield per vine, ascorbic acid and total sugar. 
The genotypic coefficient of variation exhibit genetic variability ranged from $0.78 \%$ in total phenol to $38.24 \%$ in weight of tuber. The GCV estimates in all characters showed that the genotypic variability was low $(<10 \%)$ in case of internode length, starch content, moisture, total phenol, dry matter; moderate (10-20\%) for days to emergence, first leaf emergence, number of leaves, number of sprouts per seed tuber, vine length (45 DAE), vine length at harvest, leaf width, petiole length, tuber length, diameter of tuber, stem girth, TSS and high (> 20\%) for number of tuber per vine, weight of tuber, tuber yield per vine, ascorbic acid and total sugar.

The broad sense heritability estimates have been presented in Table 2. High magnitude of heritability was recorded for most of traits. The highest heritability recorded for TSS $(99.73 \%)$, ascorbic acid $(99.66 \%)$, weight of tuber $(96.89 \%)$, total sugar $(95.79 \%)$, tuber yield per vine ( $94.59 \%)$, days to emergence $(89.48 \%)$, diameter of tuber $(86.47 \%)$, dry matter and moisture $(86.42 \%)$, number of tuber $(85.84 \%)$, leaf width $(85.03 \%)$, first leaf emergence $(84.95 \%)$, vine length 45 DAE $(83.95 \%)$, petiole length $(82.16 \%)$, vine length at harvest $(81.99 \%)$ and starch content $(81.95 \%)$. Moderate heritability were recorded for stem girth $(79.50 \%)$, tuber length $(77.09 \%)$, number of sprouts per seed tuber $(72.89 \%)$, number of leaves $(71.85 \%)$ and inter-node length (53.66 \%). Low heritability recorded for total phenol (36.05 $\%)$.

Table.1 Mean square for various characters in greater yam

\begin{tabular}{|c|c|c|c|c|}
\hline S.No & Characters & $\begin{array}{c}\text { Replication } \\
\text { [2] }\end{array}$ & $\begin{array}{c}\text { Genotype } \\
\text { [29] }\end{array}$ & $\begin{array}{c}\text { Error } \\
{[58]}\end{array}$ \\
\hline 1 & Days to emergence & 1.92 & $41.87 * *$ & 1.58 \\
\hline 2 & First leaf emergence(DAE) & 2.56 & $36.56 * *$ & 2.04 \\
\hline 3 & No. of leaves (30 DAE) & 7.84 & $274.27 * *$ & 31.68 \\
\hline 4 & No. of sprouts per seed tuber & 0.02 & $0.23 * *$ & 0.03 \\
\hline 5 & Vine length $(\mathrm{cm})$ & 6.93 & $1522.71 * *$ & 91.23 \\
\hline 6 & Internode length (cm) & 1.03 & $6.43 * *$ & 1.44 \\
\hline 7 & Vine length at harvest $(\mathrm{cm})$ & 157.92 & $8518.04 * *$ & 581.22 \\
\hline 8 & Leaf width $(\mathrm{cm})$ & 0.15 & $8.08 * *$ & 0.45 \\
\hline 9 & Petiole length $(\mathrm{cm})$ & 0.17 & $6.81 * *$ & 0.46 \\
\hline 10 & Tuber length $(\mathrm{cm})$ & 0.03 & $45.62 * *$ & 4.11 \\
\hline 11 & Diameter of tuber $(\mathrm{cm})$ & 0.10 & $6.04 * *$ & 0.30 \\
\hline 12 & Number of tuber per vine & 0.02 & $0.39 * *$ & 0.02 \\
\hline 13 & Weight of tuber (kg) & 0.00 & $0.77 * *$ & 0.01 \\
\hline 14 & Stem girth $(\mathrm{cm})$ & 0.04 & $1.11 * *$ & 0.09 \\
\hline 15 & Tuber yield per vine (kg) & 0.00 & $0.74 * *$ & 0.01 \\
\hline 16 & Starch content $(\mathrm{g} / \mathbf{1 0 0 g})$ & 0.16 & $63.53 * *$ & 4.34 \\
\hline 17 & Ascorbic acid (mg) & 0.04 & $40.22 * *$ & 0.05 \\
\hline 18 & Moisture (\%) & 0.87 & $37.36 * *$ & 1.86 \\
\hline 19 & TSS $\left({ }^{\circ} \mathbf{B}\right)$ & 0.01 & $8.56 * *$ & 0.01 \\
\hline 20 & Total sugar (g/100g) & 0.08 & $6.30 * *$ & 0.09 \\
\hline 21 & Total Phenol (mg/100g) & 0.91 & $2.46 * *$ & 0.91 \\
\hline 22 & Dry matter $(\%)$ & 0.87 & $37.36 * *$ & 1.86 \\
\hline
\end{tabular}

$*$, ** Significant at $5 \%$ and $1 \%$, respectively 
Table.2 Variability parameters for various characters in greater yam

\begin{tabular}{|c|c|c|c|c|c|c|c|}
\hline SN & Characters & GCV & PCV & ECV & $h^{2}$ & GA & GG \\
\hline 1 & Days to emergence & 19.88 & 21.02 & 6.82 & 89.48 & 7.14 & 38.74 \\
\hline 2 & First leaf emergence & 16.04 & 17.41 & 6.75 & 84.95 & 6.44 & 30.46 \\
\hline 3 & No. of leaves (30 DAE) & 10.82 & 12.76 & 6.77 & 71.85 & 15.70 & 18.89 \\
\hline 4 & No. of sprouts per seed tuber & 14.65 & 17.15 & 8.93 & 72.89 & 0.46 & 25.76 \\
\hline 5 & Vine length (45 DAE) (cm) & 15.43 & 16.84 & 6.75 & 83.95 & 41.23 & 29.12 \\
\hline 6 & Internode length(cm) & 9.75 & 13.31 & 9.06 & 53.66 & 1.95 & 14.72 \\
\hline 7 & Vine length at harvest $(\mathrm{cm})$ & 14.89 & 16.44 & 6.98 & 81.99 & 95.94 & 27.77 \\
\hline 8 & Leaf width $(\mathrm{cm})$ & 16.03 & 17.38 & 6.72 & 85.03 & 3.03 & 30.44 \\
\hline 9 & Petiole length $(\mathrm{cm})$ & 14.62 & 16.13 & 6.81 & 82.16 & 2.72 & 27.29 \\
\hline 10 & Tuber length(cm) & 13.02 & 14.83 & 7.10 & 77.09 & 6.73 & 23.55 \\
\hline 11 & Diameter of tuber(cm) & 17.86 & 19.20 & 7.06 & 86.47 & 2.65 & 34.21 \\
\hline 12 & No. of tuber per vine & 23.30 & 25.15 & 9.47 & 85.84 & 0.67 & 44.47 \\
\hline 13 & Weight of tuber(kg) & 37.57 & 38.17 & 6.73 & 96.89 & 1.02 & 76.18 \\
\hline 14 & Stem $\operatorname{girth}(\mathrm{cm})$ & 13.46 & 15.09 & 6.83 & 79.50 & 1.07 & 24.72 \\
\hline 15 & Tuber yield per vine (kg) & 28.59 & 29.40 & 6.84 & 94.59 & 0.99 & 57.28 \\
\hline 16 & Starch content $(g / 100 g)$ & 7.95 & 8.78 & 3.73 & 81.95 & 8.28 & 14.82 \\
\hline 17 & Ascorbic acid (mg) & 20.24 & 20.28 & 1.18 & 99.66 & 7.53 & 41.63 \\
\hline 18 & Moisture(\%) & 5.31 & 5.71 & 2.10 & 86.42 & 6.59 & 10.17 \\
\hline 19 & TSS $\left({ }^{\circ} \mathbf{B}\right)$ & 18.38 & 18.41 & 0.96 & 99.73 & 3.47 & 37.81 \\
\hline 20 & Total sugar (g/100g) & 20.17 & 20.61 & 4.23 & 95.79 & 2.90 & 40.67 \\
\hline 21 & Total Phenol (mg/100g) & 0.78 & 1.29 & 1.03 & 36.05 & 0.89 & 0.96 \\
\hline 22 & Dry matter (\%) & 9.77 & 10.51 & 3.87 & 86.42 & 6.59 & 18.70 \\
\hline
\end{tabular}

The data on expected genetic advance for different traits ranged from $0.46 \%$ in case of number of sprouts per seed tuber to $95.94 \%$ in vine length at harvest. Higher values of expected genetic advance ( $>20 \%)$ showed by vine length at harvest $(95.94 \%)$ and vine length 45 DAE (41.23\%). Moderate genetic advance recorded for number of leaves $(15.70$ $\%)$. Remaining traits exhibited low $(<10 \%)$ values viz., starch content $(8.28 \%)$, ascorbic acid $(7.53 \%)$, days to emergence $(7.14 \%)$, tuber length $(6.73 \%)$, dry matter and moisture $(6.59 \%)$, first leaf emergence $(6.44$ $\%)$, TSS $(3.47 \%)$, leaf width $(3.03 \%)$, total sugar $(2.90 \%)$, petiole length (2.72 \%), diameter of tuber $(2.65 \%)$, internode length $(1.95 \%)$, weight of tuber $(1.02 \%)$, stem girth $(1.07 \%)$, tuber yield per vine $(0.99 \%)$, total phenol $(0.89 \%)$, number of tuber per vine
$(0.67 \%)$ and number of sprouts per seed tuber $(0.46 \%)$.

High heritability with high genetic advance $(81.99 \%, 95.94 \%)$ recorded for vine length at harvest and $83.95 \%, 41.23 \%$ for vine length 45 DAE. Moderate heritability with moderate genetic advance $(71.85 \%, 15.70 \%)$ revealed by number of leaves.

The present experimental material exhibited a wide range of variation for high values of genotypic and phenotypic coefficient of variations were recorded for traits viz., number of tuber per vine, weight of tuber, tuber yield per vine, ascorbic acid and total sugar. The findings of these characters were supported by number of root tuber per vine (Badu et al., 2017) in sweet potato, weight of 
corm (Yadav et al., 2007) in colocasia, tuber yield per plant (Ramachandra and Srinivasa, 2017) in potato. The present research work reveal that phenotypic coefficient of variation is higher than genotypic coefficient of variation for all the characters indicating influence of environment. The findings are supported by Nwankwo and Bassey (2013); Alam et al., (2014) in greater yam, Ntui et al., (2006); Ram prasad et al., (2018)in cassava, Anshebo et al., (2004); Sharavati et al., (2018) in sweet potato, Polamuri et al., (2013); Tripura et al., (2016) in potato.

High heritability was recorded for most of traits. The highest heritability recorded for TSS followed by viz., ascorbic acid, weight of tuber, total sugar, tuber yield per vine, days to emergence, diameter of tuber, dry matter and moisture, number of tuber, leaf width, first leaf emergence, vine length $45 \mathrm{DAE}$, petiole length, vine length at harvest and starch content. Moderate heritability were recorded for stem girth, tuber length, number of sprouts per seed tuber, number of leaves and internode length. Low heritability recorded for total phenol. The findings of these characters are supported by dry matter(Mukherjee et al., 2016) in taro; vine length (Anshebo et al., 2004) in sweet potato; weight of tuber/plant, single tuber weight, tuber breadth and tuber number (Tripura et al., 2016) in potato; starch content, days taken for sprouting (Ram prasad et al., 2018) in elephant foot yam. The findings are contradictory for days to sprouting and length of corms, showing moderate heritability Kumar et al., (2017).

Higher values of expected genetic advance showed by vine length at harvest and vine length 45 DAE. The finding was supported by Mulualem and Michael (2013) for yam. Moderate genetic advance recorded for number of leaves. Remaining traits exhibited low values viz., days to emergence, tuber length, dry matter and moisture, first leaf emergence, leaf width, petiole length, diameter of tuber, internode length, weight of tuber, stem girth, tuber yield per vine, number of tuber per vine and number of sprouts per seed tuber.

Availability of high GCV \& PCV shows presence of sufficient genetic variability for evaluated traits. This indicates that there is an ample scope of selection in the present gene pool for yield and its components. The presence of large amount of variability might be due to diverse source of materials taken as well as environmental influence affecting the phenotype. Selection would be ineffective due to low expected gain or improvement in the next generation by these traits. Crop improvement depends on the magnitude of genetic variability and the extent to which the desirable characters are heritable. Heritability and genetic advance, when calculated together, would prove more useful in predicting the resultant effect of selection on phenotypic expression, without genetic advance the estimation of heritability will not be of practical value and emphasized the concurrent use of genetic advance along with heritability. Therefore, priority should be given to those traits which showed higher estimates of genetic advance as percent mean while deciding selection strategies and selection based on these characters may be useful in realizing better gain by selection.

\section{References}

Alam, S., Shylla, E., Bora, P. and Saud, B.K. 2014. Genetic variation in different cultivars of greater yam (Dioscorea alata). Journal of Root Crops, 40.

Anshebo, T., Veeraragavathatham, D. and Kannan M. 2004. Genetic variability and correlation studies in sweet potato (Ipomoea batatas L.). Madras Agricultural Journal, 91 (7-12): 420-424.

Badu, M., Ashok, P., Kiran Patro T.S.K.K. and Sasikala, K. 2017. Studies on genetic 
variability, heritability and genetic advance for growth, yield and quality parameters among orange flesh sweet potato [Ipomoea batatas (L.) Lam.] genotypes. International Journal of Current Microbiology and Applied Sciences, 6(9): 1894-1903.

Burton, G.W. 1952. Quantitative inheritance in grasses. In: Proceedings of $6^{\text {th }}$ International Grassland Congress, 1: 227-283.

Burton, G.W. and Devane, E.H. 1953. Estimating heritability in tall fescue (Festuca aruninacea) from replicated clonal material. Agronomy Journal, 45: 478-481.

Hanson, C.H., Robinson, H.F. and Comstock, R.E. 1956. Biometrical studies on yield in segregating generation in Korean lespedeza. Agronomy Journal, 48: 268-272.

Johnson, H.W., Robinson, H.F. and Comstock, R. E. 1955. Estimates of genetic and environmental variability in soyabean. Agronomy Journal, 47(7):314-318.

Kumar, A., Kushwaha, M.L., Panchbhaiya, A. and Verma, P. 2017. Studies on genetic variability in different genotypes of taro. Journal of Hill Agriculture, 8(3): 274-278.

Mukherjee, D., Roquib, M.A., Das, N.D. and Mukherjee, S. 2016. A study on genetic variability, character association and path co-efficient analysis on morphological and yield attributing characters of taro [Colocasia esculenta (L.)Schott]. Biomedical \& Life Sciences, 7(3): 479-488.

Mulualem, T. and Michael, W.G. 2013. Agronomical evaluation of aerial yam (Dioscorea bulbifera) accessions collected from South and Southwest Ethiopia. Greener Journal of Agriculture Science 3:693-704.

Nuti, V.O., Uyoh, E.A., Affangideh, U. and Egbonyi, J.P. 2006. Correlation and genetic variability in cassava. Journal of Food, Agriculture \& Environment, 4(3 \& 4): 147150.
Nwankwo, I.I.M and Bassey, E.E. 2013. A Study of variability and heritability for yield and yield related traits in guinea white yam (Dioscorea rotundata, Poir) genotypes in Umudike, South-eastern Nigeria. Wudpecker Journal of Agricultural Research 2: 122 -127.

Polamuri, A., Rajasekher, M. and Sasikala, K. 2013. Genetic variability and heritability estimation in cassava. Journal of Root Crops, 39(2).

Ramachandra, M.K. and Srinivasa, V. 2017. Variability, heritability and genetic advance for quantitative traits in potato genotypes under hill zone of Karnataka. Green Farming, 8(6): 1250-1253.

Ram Prasad, Singh, P.K. and Singh V.B. 2018. Genetic evaluation of genotypes for variability in elephant foot yam. International Journal of Current Microbiology and Applied Sciences, 7: 4673-4679.

Sharavati, M.B., Srinivasa, V., Anusha, R.B. and Shubha, A.S. 2018. Genetic variability studies in sweet potato [Ipomoea batatas (L.) Lam] genotypes under Hill zone of Karnataka. International Journal of Current Microbiology and Applied Sciences, 7(9): 850-858.

Tripura, A., Das, A., Das, B., Priya, B. and Sarkar K.K. 2016. Genetic studies of variability, character association and path analysis of yield and its component traits in potato [Solanum tuberosum (L.)]. Journal of Crop and Weed, 12(1): 56-63.

Yadav, R.K., Rai, N., Yadav, D.S. and Sanwal, S.K. 2007. Correlation, path coefficient and genetic diversity pattern in colocasia genotypes. Vegetable Science, 34(2): 153156.

\section{How to cite this article:}

Vandna, K. D. Ameta, R. A. Kaushik and Meena, M. K. 2020. Genetic Variability Analysis in Greater Yam (Dioscorea alata L.) in Southern Rajasthan conditions. Int.J.Curr.Microbiol.App.Sci. 9(08): 3920-3925. doi: https://doi.org/10.20546/ijcmas.2020.908.451 